Висновки i перспективи подальших досліджень. У процесі дослідження нам вдалося виявити основні причини погіршення здоров'я молодих людей в студентському віці та визначити комплекс педагогічних умов, дотримання і реалізація яких в освітньому процесі ВНЗ, на наш погляд, забезпечить високу якість та ефективність оволодіння майбутніми соціальними педагогами культурою професійного здоров'я, що слугуватиме основою їх здоров'язбережувальної, здоров'ятворчої навчально-професійної діяльності.

Перспективою подальших досліджень $є$ розроблення шляхів реалізації визначених педагогічних умов та створення, апробація, експериментальна перевірка ефективності технологій формування культури професійного здоров'я майбутніх соціальних педагогів.

\title{
Література
}

1. Виленский М. Я. Физическая культура в научной организации процесса обучения в высшей школе: [учеб. пособ.] / М. Я. Виленский. - М. : МГПИ, 1982. - 156 с.

2. Воскобойнікова Г. Л. Вікова фізіологія, шкільна гігієна і валеологія: [навч.метод. посіб.] / Воскобойнікова Г. Л., Головко О.Ф., Соколенко Л. С. [за ред. П. Д. Плахтія]. - Кам'янець-Подільський: ПП Буйніцький О. А., 2010. - 148 с.

3. Кон И. С. Психология ранней юности : [кн. для учителя] / И. С. Кон. - М. : Просвещение, 1989. $-255 \mathrm{c}$.

4. Кривошеєва Г. Л. Формування культури здоров'я студентів університету : автореф. дис. на здобуття наук. ступеня канд. пед. наук : 13.00 .04 / Г. Л. Кривошеєва. Луганськ, 2001. - 18 с.

5. Кириленко С. В. Соціально-педагогічні умови формування культури здоров'я старшокласників : автореф. дис. на здобуття наук. ступеня канд. пед. наук : 13.00 .04 / С. В. Кириленко. - К., 2004. $-17 \mathrm{c}$.

6. Міхєєва Л. Особливості формування здорового способу життя у молодого покоління / Л.Міхєєва // Освіта регіону. - 2011. - №3. - С. 318-321.

7. Новиков А. М. Как работать над диссертацией : [пособ. для начинающего педагогаисследователя] / А. М. Новиков. - [ 2-е изд.]. - М. : ИПК и ПРНОМО, 1996. - 112 с.

8. Яковлева Н. М. Теория и практика подготовки будущего учителя к творческому решению воспитательных задач : дис. ... докт. пед. наук / Н. М. Яковлева. - Челябинск, 1992. $-403 \mathrm{c}$.

Стаття надійшла до редакції 9.05.2012 p.

УДК $37.09+378$

К. П. Нечипоренко, викладач, Київський університет імені Бориса Грінченка

\section{ІНТЕЛЕКТУАЛЬНО-ТВОРЧІ ВМІННЯ У СТРУКТУРІ ОСОБИСТОСТІ МАЙБУТНЬОГО ВЧИТЕЛЯ ПОЧАТКОВОЇ ШКОЛИ}

Нечипоренко К. П. Інтелектуально-творчі вміння у структурі особистості майбутнього вчителя початкової школи.

У статті розкрито зміст інтелектуально-творчих умінь та обтрунтовано їх місие у структурі особистості майбутнього вчителя початкової школи.

Ключові слова: інтелектуально-творчі вміння, особистість майбутнього вчителя початкової школи. 
Нечипоренко К. П. Интеллектуально-творческие умения в структуре личности будущего учителя начальной школьл.

В статье раскрыта сущность интеллектуально-творческих умений и обоснованно их место в структуре личности будущего учителя начальной школьы.

Ключевые слова: интеллектуально-творческие умения, личность будущего учителя начальной школьь.

Nechiporenko K. Intellectual and creative skills in the structure of a future elementary school teacher.

The article analyses the content of the intellectually-creative skills and groundes their place in the structure of personality of future teachers of elementary school.

Key words: intellectually-creative skills, personality of future teachers of elementary school.

Актуальність проблеми дослідження. В умовах інтеграції системи освіти України до європейського освітнього простору необхідною є зміна пріоритетів у підготовці майбутніх педагогів. Зокрема, відповідно до Болонської декларації важливим завданням уважають підвищення якості освіти. У чинному законі України «Про вищу освіту» зазначено, що якість освіти - це сукупність якостей особи з вищою освітою, що відображає ії професійну компетентність, ціннісну орієнтацію, соціальну спрямованість $і$ зумовлює здатність задовольняти як особисті духовні і матеріальні потреби, так і потреби суспільства.

Якість навчально-виховного процесу у загальноосвітньому навчальному закладі залежить від професійної компетентності сучасного вчителя. Професійна компетентність вчителя $є$ основою його конкурентоздатності на ринку праці. Важливим компонентом у структурі особистості конкурентоздатного фахівця $\epsilon$, на нашу думку, інтелектуально-творчі уміння. 3 огляду на вище зазначене, професійна підготовка майбутнього вчителя початкової школи має бути спрямована на формування передовсім професійних умінь, серед яких провідними є інтелектуально-творчі.

Аналіз наукових досліджень та публікацій. Дослідженням проблеми формування особистості майбутнього вчителя у процесі професійної підготовки опікувалися науковці С. Архангельський, А. Бойко, В. Слканов, I. Зязюн, Н. Кузьміна, А. Макарова, Н. Нікітіна, С. Сисоєва, В. Сластьонін, М. Фіцула, Б. Шиян та інші. Методи активного навчання розглядали А. Гін, С. Гончаров, Б. Житник, Л. Корнєєва, Г. Селевко та інші. На доцільність і необхідність використання інновацій у підготовці фахівців звертали увагу В. Бабурін, Я. Бєльчиков, М. Бірштейн, А. Вербицький, С. Гідрович, Т. Долбенко, В. Єфімов, А. Смолкін, Т. Хлєбнікова, В. Христинко, П. Щербань та інші.

Про важливість інтелектуального розвитку взагалі, інтелектуальних умінь людини, зокрема, зазначали Ш. Амонашвілі, Б. Ананьєв, О. Башманівський, Н. Бібік, 3. Калмикова, О. Митник, В. Паламарчук, Ж. Піаже, С. Рубінштейн, Е. Торндайк та інші.

Питання розвитку творчих умінь особистості досліджували В. Андреєв, В. Беспалько, Л. Виготський, Г. Костюк, В. Моляко, Я. Пономарьов, О. Савченко, В. Сухомлинський, М. Шуть, І. Якиманська та інші.

Метою статті є розкриття сутності та місця інтелектуально-творчих умінь у структурі особистості майбутнього вчителя початкової школи. 
Виклад основного матеріалу. Завдання сучасної педагогічної освіти формування та розвиток у структурі особистості вчителя конкурентоздатності як складника його професійної компетентності.

Конкурентоздатність, на думку В. Бондаря, визначається як стійка особистісна властивість - вміння свідомо і творчо реалізувати професійну компетентність за достатнього рівня володіння необхідними суспільнокомунікативними знаннями, вміннями та особистісними характеристиками.

Здатність конкурувати зумовлена, по-перше, індивідувально-психологічними ресурсами фахівця (психофізичне здоров'я, вік, зовнішність, здібності, талант, рівень інтелекту, запас енергії) та морально-етичними аспектами (ієрархія цінностей, система вірування, наявність табу та особистісних обмежень (А. Кірсанов, Ф. Найт, Д. Паригін та інші)).

По-друге, особистісний складник професійної компетентності конкурентоздатність - виявляється у рівнях розвитку:

- мотиваційно-ціннісного компонента, що відображає такі орієнтації, як спрямованість на морально-етичне самовдосконалення, передбачається позитивна настанова на соціально значущу активність, потреба в самоактуалізації, самоствердженні, самореалізації, самодисципліні;

- емоційно-вольового компонента, що передбачає відповідальність, самостійність, ініціативність, упевненість у собі, співчуття, самоконтроль тощо;

- оцінювально-регулювального компонента, що виявляється у дієвих навичках самооцінювання, саморегуляції, гнучкості, стратегічного планування, дослідницькій особистісній позиції тощо [3].

Отже, кваліфікаційно-особистісна готовність педагога складається 3 трьох структур: професійної готовності, психолого-педагогічних якостей та соціально-перцептивних навичок конкурентної боротьби.

Можна зробити висновок, що зовнішньо-професійна i внутрішньоособистісна готовність, набуваючи цілісності в процесі підготовки спеціаліста, інтегруються в систему пізнавальних, особистісних, поведінкових якостей - основи компетентності, спроможності конкурувати можуть бути визначені через ступінь сформованості та здатності вийти переможцем у конкурсній боротьбі конкурентоспроможних фахівців.

Конкурентоздатного фахівця характеризує сформованість єдиного комплексу професійних знань, умінь, навичок та психолого-педагогічних якостей.

Знання $\epsilon$ безпосереднім інструментом практичних педагогічних дій та методологічним фундаментом професійної діяльності. Знання є належним теоретичним підгрунтям педагогічних умінь. На думку Л. Спіріна, педагогічні уміння - це психологічні утворення, які об'єднують професійнозначущі особистісні якості, знання та навички з розумовими та практичними діями, що забезпечують успіх у навчально-виховній роботі. Ступінь сформованості та рівень розвитку умінь залежить від якостей особистості, від характеру та змісту професійних знань та досвіду, які вбирають у себе розумові та практичні дії під час розв'язування щоденних педагогічних задач. Професійно-педагогічні вміння О. Абдуліна характеризує як творче, свідоме володіння способами, прийомами організації педагогічного процесу. 
Вивчення досвіду практичної діяльності педагогів і ознайомлення 3 передовою практикою професійної підготовки майбутніх вчителів у нашій країні дозволили визначити інтелектуально-творчі уміння як педагогічні уміння, які є одними 3 основних складників професійної компетентності майбутнього вчителя початкової школи.

Тривалий період інтелектуальні та творчі вміння розглядали окремо $\mathrm{i}$ частіше, творчі вміння - у структурі інтелектуальних.

На сучасному етапі розвитку науки поняття «інтелектуально-творчі вміння» не є дослідженим повною мірою. Не існує і єдиного визначення цього поняття. Основою поняття «інтелектуально-творчі вміння» $є$ поняття «інтелектуальні вміння» та «творчі вміння». У процесі розвитку педагогічної та психологічної науки було сформульовано ці поняття, визначено умови їх формування, зроблено класифікацію та виокремлено основні рівні формування «інтелектуальних умінь» та «творчих умінь».

Інтелектуально-творчі вміння $є$ синтезом інтелектуальних та творчих умінь; це здатність людини не лише накопичувати знання, а й використовувати ïx у практичній діяльності, створюючи новий або покращений продукт.

До інтелектуально-творчих умінь О. Митник відносить: 1) уміння планувати свої дії на кілька кроків уперед; 2) уміння розмірковувати; 3) уміння довести власну думку; 4) уміння створювати власні «продукти», а саме: казки, вірші тощо, використовуючи навчальний матеріал. Пропонуємо доповнити запропоновані О. Митником інтелектуально-творчі вміння такими:

a) конструктивно працювати з літературою, визначати певні проблеми, формуючи переконливі ідеї щодо розв'язання виявлених проблем;

б) визначати поняття через найближчу родову та видову відмінність;

в) будувати правильні умовиводи на основі фактів, окремих наукових понять.

Студент має уміти аналізувати, визначати головне, порівнювати, доводити й узагальнювати, тобто виконувати завдання комбінованого і творчого характеру.

Узагальнюючи класифікації інтелектуальних і творчих умінь, ми пропонуємо до інтелектуальних умінь відносити: уміння визначати, аналізувати, порівнювати, синтезувати, встановлювати причинно-наслідкові зв'язки, конкретизувати, систематизувати, класифікувати, доводити, обгрунтовувати, узагальнювати.

До творчих умінь ми відносимо такі: бачити деталі, формувати нові положення, прогнозувати, генерувати ідеї, фантазувати.

До інтелектуально-творчих умінь, як синтезу інтелектуальних та творчих умінь, відносимо всі вище зазначені уміння.

На нашу думку, інтелектуально-творчі вміння вчителя - це вміння організовувати навчально-творчу діяльність учнів та створювати власні «продукти творчості»: різноманітні навчальні завдання для учнів початкової школи з математики, української мови, логіки, читання та інших навчальних предметів, науково-методичні розробки.

Зважаючи на вище зазначене, професійна підготовка майбутнього вчителя початкової школи має бути спрямована на розвиток його 
інтелектуально-творчих умінь та забезпечення його готовності до формування інтелектуально-творчих умінь учнів - уміння організовувати навчально-творчу діяльність дітей, створювати власні «продукти творчості», вміння прогнозувати, моделювати, досліджувати, пізнавати, творити та оцінювати. Для цього важливо в процесі вивчення фахових методик вводити завдання розвивального характеру, завдання, спрямовані на розвиток організаційних, діагностичних та інтелектуально-творчих умінь.

Висновки. Інтелектуально-творчі вміння посідають важливе місце у структурі особистості майбутнього вчителя початкової школи. Їх сформованість допоможе забезпечити конкурентоздатність майбутнього вчителя на ринку праці.

Розвиток інтелектуально-творчих умінь студентів - складний, цілеспрямований, систематичний та міжпредметний процес. Без систематичного виконання завдань розвивального та творчого характеру неможливо розвинути у студентів інтелектуально-творчі уміння. Для людини, у якої розвинені зазначені уміння, характерним $є$ самостійне визначення мети, інтерес до навчання, допитливість, постановка перед собою цілей та планування роботи, аналіз та визначення необхідних знань для розв'язання завдання, прогнозування результату, сміливе висування нових ідей (шляхів подолання труднощів при виконанні завдання), фантазування (якщо цього вимагає завдання) та обгрунтування своєї думки, самокритика та адекватна оцінка продуктів своєї праці. Такий студент зможе мати високі досягнення в навчанні в університеті, у майбутній професії, а під час своєї педагогічної діяльності зможе успішно реалізувати поставлені завдання щодо навчання та виховання учнів. Він зможе підготувати мислячих та інтелектуально-розвинених учнів, особистостей, які будуть не тільки використовувати знання, а й на їх основі продукувати нові креативні розв'язки поставленої проблеми.

\section{Література}

1. Галузевий стандарт вищої школи. Освітньо-професійна пограма підготовки бакалавра за спеціальністю 6.010100: « Початкове навчання». - К., 2006. - 140 с.

2. Митник О. Я. Підготовка майбутнього вчителя до формування культури мислення молодшого школяра : теорія і практика : [монографія] / Олександр Якович Митник. - Тернопіль : Мандрівець, 2009. - 368 с.

3. Навчання у початковій школі як цілісний творчий процес: теорія і практика / за ред. В. І. Бондаря ; упорядкув. О. Я. Митника. - К. : Початкова школа, 2011. - 384 с.

4. Савченко О. Я. Дидактика початкової школи: [підручник для студ. пед. фак-тів] / Олександра Яківна Савченко. - К. : Абрис, 1997. - 416 с.

5. Серьожникова Р. К. Бінарна професійно-педагогічна освіта як передумова формування творчого педагогічного потенціалу майбутнього викладача / Р. К. Серьожникова // Наукові праці. Серія : Педагогіка, психологія і соціологія. Випуск 7. - Донецьк : ДВНЗ «ДонНТУ», 2010. - 237 с.

Стаття надійшла до редакції 25.05.2012 р. 